\title{
PENGEMBANGAN APLIKASI PERHITUNGAN ENERGI MENGGUNAKAN FORMULA HARRIS BENEDICT UNTUK MEMBANTU DALAM MENENTUKAN KEBUTUHAN GIZI IBU HAMIL
}

\author{
Myrna Dwi Rahmatya ${ }^{1}$, Rauf Fauzan ${ }^{2}$, Annisa Paramitha Fadillah ${ }^{3}$, \\ Nizar Rabbi Radliya ${ }^{4}$, Yusran Panca Putra ${ }^{5}$ \\ Prodi Sistem Informasi, Fakultas Teknik dan Ilmu Komputer, Universitas Komputer Indonesia \\ J1 Dipati Ukur No 112-116, Bandung 40132 \\ myrna@email.unikom.ac.id ${ }^{1}$, rauffauzan@email.unikom.ac.id ${ }^{2}$, annisa@email.unikom.ac.id ${ }^{3}$, \\ nizar@email.unikom.ac.id ${ }^{4}$, yusranpanca@gmail.com ${ }^{5}$
}

\begin{abstract}
ABSTRAK
Survei Demografi dan Kesehatan Indonesia (SDKI) tahun 2012 menyatakan bahwa status gizi ibu selama kehamilan penting baik bagi perkembangan bayi di dalam rahim. Gizi merupakan zat-zat yang didapat dari makanan (karbohidrat, lemak, dan protein, oksidasi) yang dapat menghasilkan energi untuk kebutuhan tubuh dalam melakukan aktivitas. Jadi untuk mengetahui kebutuhan gizi seseorang harus dilakukan perhitungan energi yang dibutuhkan. Perhitungan kebutuhan energi dapat dilakukan dengan menggunakan formula Harris Benedict. Formula Harris Benedict digunakan untuk menghitung jumlah kalori (satuan energi) yang dibutuhkan seseorang setiap harinya. Dalam proses perhitungannya formula Harris Benedict membutuhkan nilai BMR (Basal Metabolic Rate). Energi tersebut dibutuhkan untuk beberapa fungsi vital tubuh seperti bernapas, denyut jantung, pengaturan suhu tubuh, pemeliharaan tonus otot, sekresi enzim, metabolisme makanan, sekresi hormon, dan transmisi elektrik pada otot. Khusus untuk ibu hamil nilai BMR ini akan ditambahkan dengan angka kecukupan gizi berdasarkan usia kehamilan (trimester kehamilan). Faktor yang lain yang mempengaruhi nilai kebutuhan energi adalah tingkat aktivitas fisik, usia, berat badan dan tinggi badan. Perhitungan formula Harris Benedict akan diimplementasikan dengan memanfaatkan teknologi informasi, dalam bentuk pengembangan aplikasi. Dari uraian diatas, penliti bermaksud melakukan pengembangan aplikasi berbasis android dan web untuk perhitungan energi menggunakan formula Harris Benedict. Hasil dari perhitungan energi dapat digunakan untuk membantu ibu hamil dalam menentukan kebutuhan gizi, sehingga penelitian ini bertujuan untuk membantu ibu hamil dalam menjaga status gizi selama masa kehamilan.
\end{abstract}

Kata Kunci : Pengembangan Aplikasi, Gizi Ibu Hamil, Formula Harris Benedict

\section{PENDAHULUAN}

Survei Demografi dan Kesehatan Indonesia (SDKI) tahun 2012 menyatakan bahwa status gizi ibu selama kehamilan sangat penting baik bagi perkembangan bayi di dalam rahim maupun perlindungan terhadap kesakitan dan kematian ibu (BPS, BKKBN dan Kementrian Kesehatan, 2012). Status gizi didefinisikan sebagai status kesehatan yang dihasilkan oleh keseimbangan antara kebutuhan dan masukan nutrisi. Salah satu contoh penyakit ibu hamil yang disebabkan oleh status gizi adalah penyakit kekurangan energi kronik (Vita K.M., 2014). Sedangkan dampak yang diterima oleh bayi yang dilahirkan oleh ibu yang kurang gizi adalah Bayi Berat Lahir Rendah (BBLR). Bayi dengan BBLR ini mempunyai peluang kematian 10 sampai 20 kali lebih besar dari pada bayi yang lahir dengan berat lahir cukup (Almatsier S., 2011). Atas dasar tersebut maka status gizi ibu hamil menjadi sangat penting untuk diperhatikan karena dapat memberikan resiko penyakit serta kematian pada ibu dan bayi.

Gizi merupakan zat-zat yang didapat dari makanan (karbohidrat, lemak, dan protein, oksidasi) yang dapat menghasilkan energi untuk kebutuhan tubuh dalam melakukan aktivitas (Almatsier S., 2011). Jadi untuk mengetahui kebutuhan gizi seseorang harus dilakukan perhitungan energi yang dibutuhkan. Perhitungan kebutuhan energi dapat dilakukan dengan menggunakan formula Harris Benedict.

Formula Harris Benedict digunakan untuk menghitung jumlah kalori (satuan energi) yang dibutuhkan seseorang setiap harinya. Dalam proses perhitungannya formula Harris Benedict membutuhkan nilai Basal Metabolic Rate (BMR). BMR merupakan. Khusus untuk ibu hamil nilai BMR ini akan ditambahkan dengan angka 
kecukupan gizi berdasarkan usia kehamilan (trimester kehamilan). Faktor yang lain yang mempengaruhi nilai kebutuhan energi adalah tingkat aktivitas fisik, usia, berat badan dan tinggi badan.

Perhitungan formula Harris Benedict akan diimplementasikan dengan memanfaatkan teknologi informasi, dalam bentuk pengembangan aplikasi. Aplikasi yang dikembangkan menggunakan pemrograman mobile berbasis android serta dilengkapi dengan aplikasi berbasis web. Penentuan basis aplikasi dilakukan berdasarkan kemudahan akses pengguna yaitu ibu hamil. Dengan dibangunnya aplikasi ini maka diharapkan dapat membantu ibu hamil dalam menyediakan informasi mengenai kebutuhan gizi untuk kesehariannya. Hasil perhitungan energi menggunakan formula Harris Benedict akan ditransformasi ke dalam bentuk rekomendasi menu makanan. Hal ini dimaksudkan untuk membantu ibu hamil dalam mencapai status gizi sesuai energi yang yang dibutuhkan. Daftar menu makanan yang direkomendasikan sudah diatur sehingga sesuai dengan energi yang dibutuhkan berdasarkan unsur protein, lemak dan karbohidrat.

Aplikasi yang dikembangkan akan diuji coba pada kelompok ibu hamil (pasien) di sebuah rumah bersalin. Sehingga pada penelitian ini akan menggunakan studi kasus sebagai objek penelitian yaitu Klinik Utama Ibu dan Anak Melong Asih. Adanya penggunaan studi kasus, diharapkan aplikasi yang dikembangkan dapat diterapkan diberbagai klinik atau rumah sakit bersalin sebagai sarana penunjang pelayanan kesehatan oleh dokter kandungan, ahli gizi tarhadap ibu hamil.

Dari uraian diatas, penliti bermaksud untuk melakukan pengembangan aplikasi berbasis android dan web untuk perhitungan energi menggunakan formula Harris Benedict. Hasil dari perhitungan energi dapat digunakan untuk membantu ibu hamil dalam menentukan kebutuhan gizi, sehingga diharapkan dengan adanya aplikasi ini maka ibu hamil dapat menjaga status gizi selama masa kehamilan.

\section{A. Rumusan Masalah}

Berdasarkan uraian latar belakang penelitian maka didapatkan rumusan masalah sebagai berikut:

1. Bagaimana perhitungan energi untuk kebutuhan ibu hamil menggunakan formula Harris Benedict?

2. Bagaimana implementasi formula Harris Benedict dalam bentuk pengembangan aplikasi (perangkat teknologi informasi)?

3. Bagaimana mengembangkan aplikasi untuk melayani ibu hamil dalam hal pelayanan gizi selama masa kehamilan?

\section{B. Tujuan Penelitian}

Penelitian ini memiliki tujuan sebagai berikut:

1. Untuk mengetahui perhitungan energi untuk kebutuhan ibu hamil menggunakan formula Harris Benedict.

2. Untuk melakukan implementasi formula Harris Benedict dalam bentuk pengembangan aplikasi (perangkat teknologi informasi).

3. Untuk mengembangkan aplikasi untuk melayani ibu hamil dalam hal pelayanan gizi selama masa kehamilan.

\section{KAJIAN PUSTAKA}

\section{A. Gizi Ibu Hamil}

Gizi merupakan zat-zat yang didapat dari makanan (karbohidrat, lemak, dan protein, oksidasi) yang dapat menghasilkan energi untuk kebutuhan tubuh dalam melakukan aktivitas (Almatsier S., 2011). Jadi untuk mengetahui kebutuhan gizi seseorang harus dilakukan perhitungan energi yang dibutuhkan. Gizi ibu selama kehamilan sangat penting baik bagi perkembangan bayi di dalam rahim maupun perlindungan terhadap kesakitan dan kematian ibu (BPS, BKKBN dan Kementrian Kesehatan, 2012). Status gizi didefinisikan sebagai status kesehatan yang dihasilkan oleh keseimbangan antara kebutuhan dan masukan nutrisi. Salah satu contoh penyakit ibu hamil yang disebabkan oleh status gizi adalah penyakit kekurangan energi kronik (Vita K.M., 2014). Sedangkan dampak yang diterima oleh bayi yang dilahirkan oleh ibu yang kurang gizi adalah Bayi Berat Lahir Rendah (BBLR). Bayi dengan BBLR ini mempunyai peluang kematian 10 sampai 20 kali lebih besar daripada bayi yang lahir dengan berat lahir cukup (Almatsier S, 2011).

\section{B. Formula Harris Benedict}

Hal yang paling utama dalam menentukan kebutuhan energi yang dibutuhkan oleh manusia adalah Basal Metabolic Rate (BMR) dan aktivitas fisik. Pada penelitian ini dalam menentukan nilai BMR menggunakan formula Harris Benedict. Persamaan formula Harris Benedict yang digunakan adalah perhitungan BMR untuk perempuan (dalam hal ini adalah ibu hamil). Persamaan tersebut dapat dilihat pada persamaan di bawah ini: 
Ket :

$\mathrm{BB}=$ Berat Badan $(\mathrm{kg})$

$\mathrm{TB}=$ Tinggi Badan $(\mathrm{cm})$

$\mathrm{U} \quad=$ Umur dalam tahun

Persamaan untuk menghitung kebutuhan energi berdasarkan aktivitas fisik dapat dilihat pada persamaan di bawah ini:

Perhitungan kebutuhan energi = BMR x Nilai Faktor Aktivitas

Dalam menentukan nilai faktor aktivitas berdasarkan aktivitas fisik dapat dilihat pada Tabel 2.1 di bawah ini.

Tabel 2.1 Nilai Faktor Aktivitas Perempuan

\begin{tabular}{|c|l|c|}
\hline Aktivitas & \multicolumn{1}{|c|}{ Jenis Kegiatan } & Faktor Aktivitas \\
\hline Sangat Ringan & $100 \%$ waktu untuk berdiri atau duduk & 1,30 \\
\hline Ringan & $\begin{array}{l}\text { 75\% waktu untuk berdiri atau duduk } \\
25 \% \text { waktu untuk aktivitas lain }\end{array}$ & 1,55 \\
\hline Sedang & $\begin{array}{l}\text { 60\% waktu untuk duduk atau berdiri } \\
40 \% \text { waktu untuk aktivitas lain }\end{array}$ & 1,70 \\
\hline Berat & $\begin{array}{l}40 \% \text { waktu untuk berdiri atau duduk } \\
60 \% \text { waktu untuk aktivitas lain }\end{array}$ & 2,00 \\
\hline
\end{tabular}

(Sumber: Almatsier S, 2011)

Setelah didapatkan jumlah kalori yang dibutuhkan dalam satu hari, khusus untuk kasus ibu hamil jumlah kalori yang dibutuhkan akan dijumlahkan dengan angka kecukupan gizinya sesuai dengan trimester kehamilan. Angka kecukupan gizi untuk ibu hamil dapat dilihat pada table 2.2 di bawah ini.

Tabel 2.2 Angka Kecukupan Gizi Ibu Hamil

\begin{tabular}{|l|l|l|l|l|}
\hline & Energi & Protein & Lemak & Karbohidrat \\
\hline Trimester 1 & +180 & +20 & +6 & +25 \\
\hline Trimester 2 & +300 & +20 & +10 & +40 \\
\hline Trimester 3 & +300 & +20 & +10 & +40 \\
\hline
\end{tabular}

(Sumber: Menteri Kesehatan Republik Indonesia, 2013)

\section{METODE PENDEKATAN DAN PENGEMBANGAN SISTEM}

\section{A. Metode Penelitian}

Penelitian ini menggunakan metode R\&D. Dasar pemilihan metode dikarenakan penelitian ini bertujuan untuk menghasilkan produk berupa aplikasi perangkat lunak. Metode R\&D yang digunakan akan sangat berperan pada kegiatan perancangan dan uji coba aplikasi yang dikembangankan.

\section{B. Pendekatan dan Pengembangan Sistem}

Pada penelitian ini akan dilakukan pengembangan perangkat lunak. Oleh sebab itu maka dibutuhkan metode pendekatan dan pengembangan sistem. Metode pendekatan sistem yang digunakan adalah pendekatan berorientasi objek.

Metode pengembangan sistem yang digunakan adalah RUP (Rational Unified Process). Berikut gamar Arsitektur RUP: 


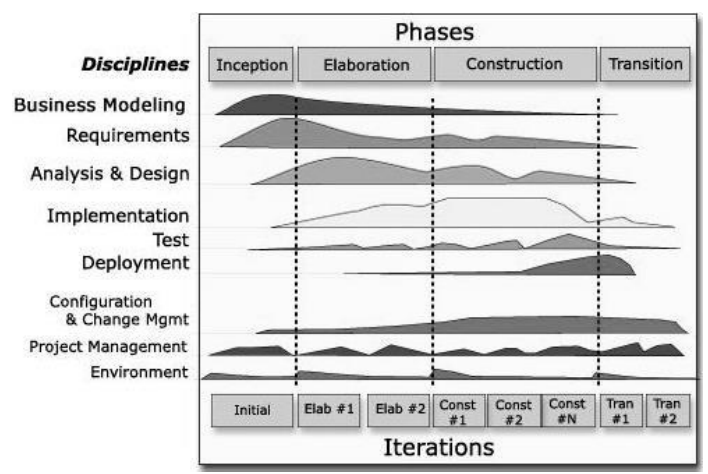

Gambar 3.1 Arsitektur RUP (Rational Unified Process) (Sumber:

Rosa dan Shalahuddin, 2013)

\section{Prosedur Penelitian}

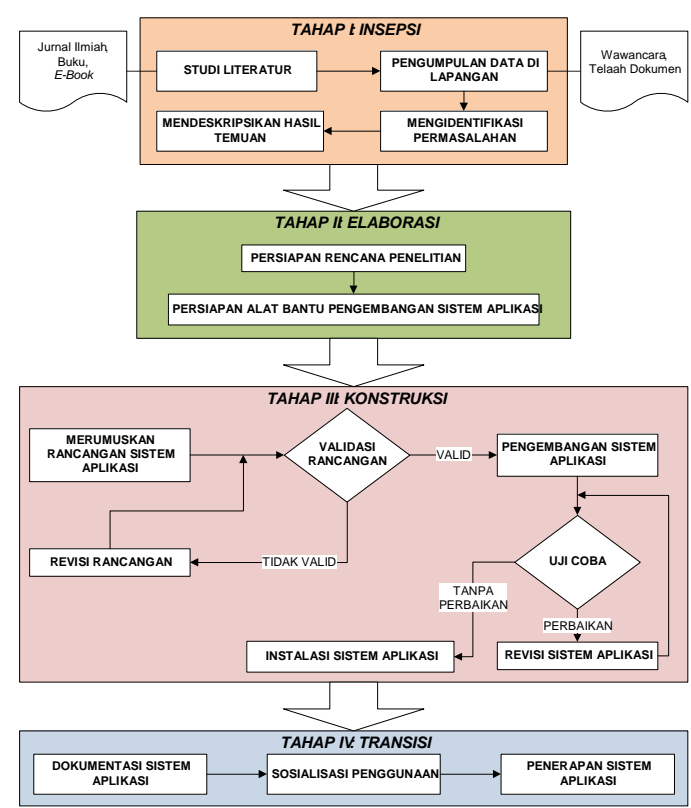

Gambar 3.2 Prosedur Penelitian

\section{HASIL DAN PEMBAHASAN}

\section{A. Analisis Sistem yang Berjalan}

Analisis prosedur penentu kebutuhan gizi ibu hamil di klinik dilakukan agar kita dapat mengetahui secara lebih rinci bagaimana proses konsultasi berjalan agar dapat kita jadikan proses secara komputerisasi.

Berikut prosedur penentu kebutuhan gizi ibu hamil di klinik:

1. Kedatangan klien (ibu hamil) ibu hamil ke klinik.

2. Melakuan pendaftaran ke pihak administrasi dengan menyerahkan data diri.

3. Ibu hamil mendapatkan kartu pasien.

4. Melakukan pemeriksaan meliputi tinggi badan, berat badan tingkat aktivitas, usia kehamilan dan umur.

5. Bertemu dengan ahli gizi untuk melakukan konsultasi.

\section{B. Use Case yang Sedang Berjalan}

Use case diagram adalah diagram untuk memperlihatkan hubungan diantara actor dan use case. Berikut adalah gambar use case diagram pada proses penentu kebutuhan gizi di klinik: 


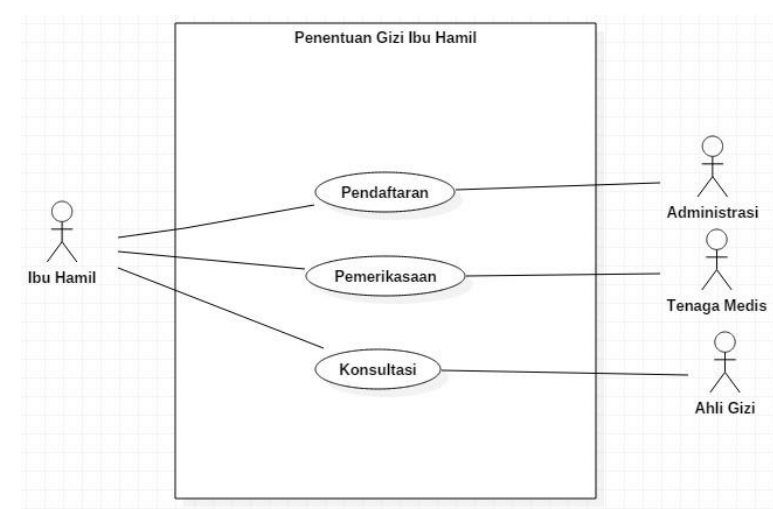

Gambar 4.1 Use Case Doagram Sistem yang Berjalan

\section{Evaluasi Sistem yang Sedang Berjalan}

Dari prosedur yang sedang berjalan dapat kita lihat bahwa berkonsultasi langsung kepada ahli gizi akan sangat merepotkan untuk ibu hamil dikarenakan kondisi tubuh dan perut yang membesar akan membuat ibu hamil kesulitan untuk berpergian kemana-mana.

Solusi nya adalah dengan membuat ibu hamil mampu melakukan pengecekan kebutuhan gizi dirumah tanpa bantuan ahli gizi, yaitu dengan cara membuat aplikasi penentu kebutuhan gizi ibu hamil berbasis android sehingga ibu hamil mampu melakukan pengecekan kebutuhan gizinya dirumah.

Tabel 5.6 Evaluasi Sistem yang Berjalan

\begin{tabular}{|l|l|l|}
\hline No & Masalah & Solusi \\
\hline 1 & $\begin{array}{l}\text { Tingkat kematian ibu hamil masih tinggi yang secara } \\
\text { tidak langsung disebabkan oleh kurangnya } \\
\text { pengetahuan ibu hamil terhadap kebutuhan gizi. }\end{array}$ & $\begin{array}{l}\text { Mendapatkan aplikasi yang dapat memberikan } \\
\text { pengetahuan tentang kebutuhan gizi ibu hamil, } \\
\text { sehingga dapat menurunkan angka kematian ibu } \\
\text { hamil yang disebabkan oleh hal tersebut. }\end{array}$ \\
\hline 2 & $\begin{array}{l}\text { Belum adanya aplikasi yang dapat melakukan } \\
\text { perhitungan kebutuhan gizi ibu hamil berbasis } \\
\text { android untuk setiap hari, sehingga ibu hamil harus } \\
\text { selalu berkonsultasi (tatap muka) dengan ahli gizi. }\end{array}$ & $\begin{array}{l}\text { Mendapatkan aplikasi yang dapat melakukan } \\
\text { perhitungan kebutuhan gizi ibu hamil } \\
\text { menggunakan rumus Harris Benedict. }\end{array}$ \\
\hline 3 & $\begin{array}{l}\text { Belum adanya aplikasi yang dapat menjadi sarana } \\
\text { penunjang layanan ahli gizi terhadap pasien (ibu } \\
\text { hamil). }\end{array}$ & $\begin{array}{l}\text { Mendapatkan aplikasi yang dapat menjadi sarana } \\
\text { atau media pelayan antara ahli gizi dengan pasien } \\
\text { (ibu hamil) di klinik buah hati. }\end{array}$ \\
\hline
\end{tabular}

\section{Perancangan Sistem}

Perancangan sistem merupakan tahap yang dilakukan setelah melakukan analisa sistem yang berjalan untuk dilakukan perancangan system yang akan dibangun secara terperinci, meliputi penggambaran dan perencanaan system secara menyeluruh yang saling berhubungan antara pengguna, perangkat lunak dan perangkat keras.

Adapun gambaran umum dari aplikasi yang diusulkan oleh penulis adalah sebagai berikut:

1. Aplikasi Penentu Kebutuhan Gizi Ibu Hamil Berbasis Android dibuat dengan bahasa pemrograman PHP dan Microframework slim untuk bagian backend dan Ionic framework untuk bagian user interface.

2. Database yang digunakan untuk membangun Aplikasi Penentu Kebutuhan Gizi Ibu Hamil Berbasis Android adalah MYSQL.

3. Aplikasi Penentu Kebutuhan Gizi Ibu Hamil Berbasis Android mampu menampilkan artikel tentang kehamilan, melakukan fungsi perhitungan kebutuhan kalori perhari dan memberikan saran berupa makanan yang mampu memenuhi kebutuhan kalori tersebut, serta mampu melakukan pengecekan untuk melihat apakah kebutuhan gizi ibu hamil sudah terpenuhi atau belum.

4. Aplikasi Penentu Kebutuhan Gizi Ibu Hamil Berbasis Android mampu menjadi sarana konsultasi bagi users untuk bisa mengajukan pertanyaan ke ahli gizi.

5. Tenaga medis bertugas mengolah data makanan sera mengolah data user.

6. Ahli Gizi bertugas menjawab pertanyaan yang diajukan ibu hamil sebagai user. 
Use case diagram digunakan untuk menggambar secara ringkas siapa yang menggunakan sistem dan apa saja yang bisa dilakukannya. Berikut adalah use case diagram sistem yang diusulkan.

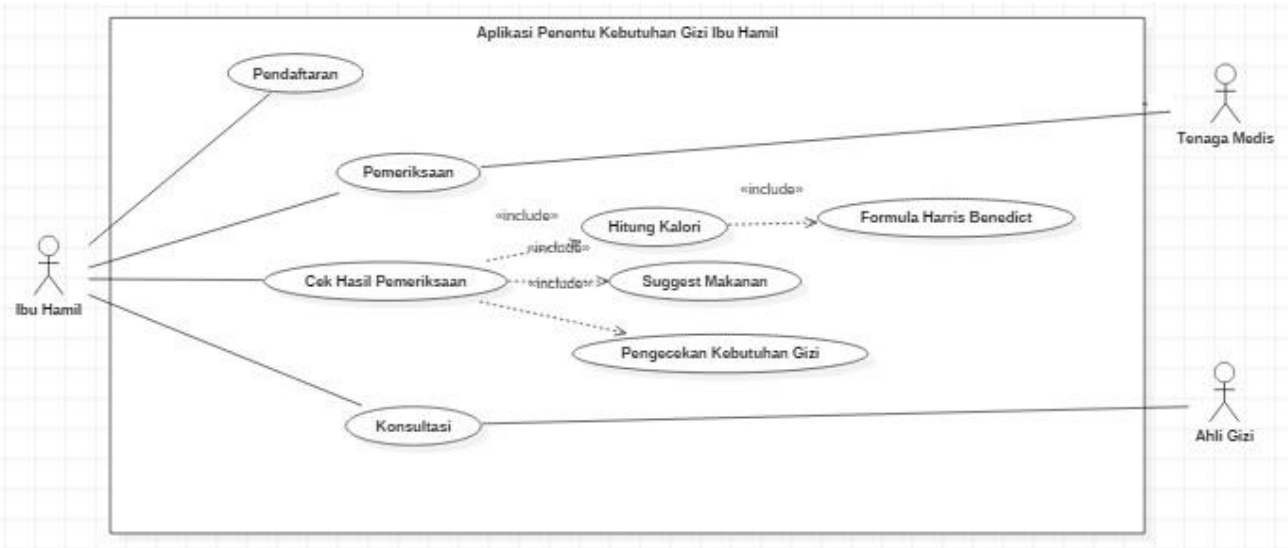

Gambar 4.2 Use Case Diagram yang Diusulkan

\section{E. Perancangan Data (Class Diagram)}

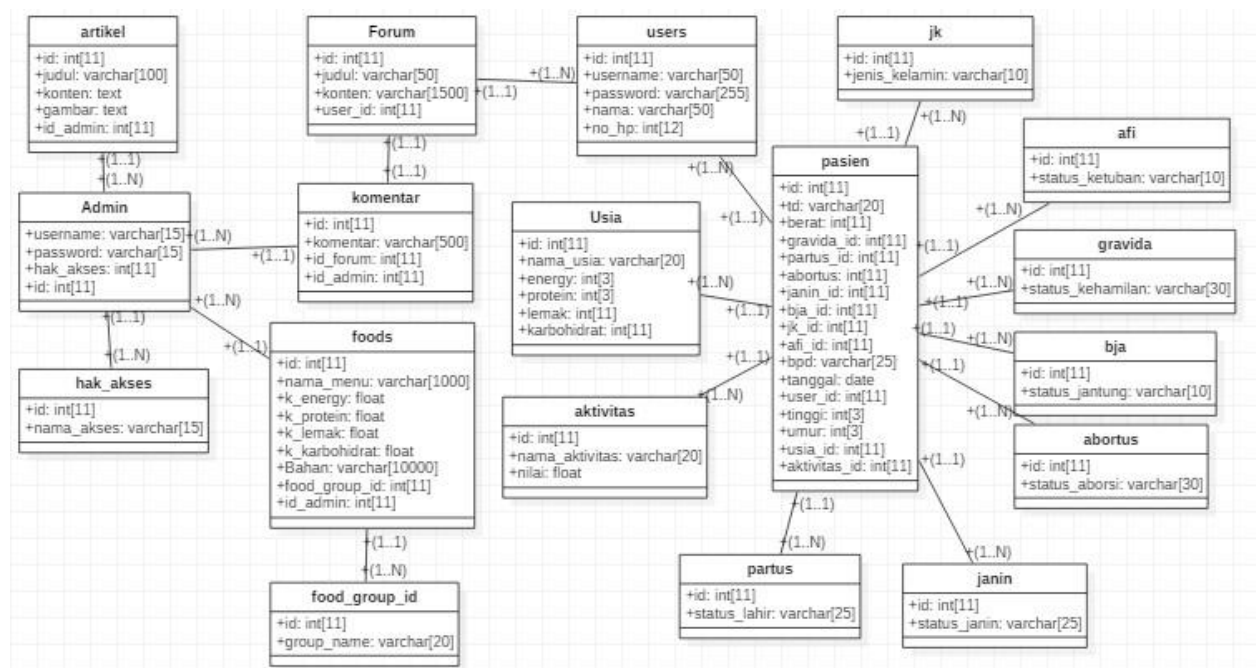

Gambar 4.2. Perancangan Data menggunakan Class Diagram

\section{F. Perancangan Jaringan}

Perancangan Arsitektur Jaringan merupakan rancangan arus komunikasi, pada pengembangan aplikasi ini memiliki dua bagian, yaitu website dan juga mobile. Website untuk bagian pengelola, dan mobile untuk user. Berikut perancangan arsitektur jaringan pada sistem yang diusulkan.

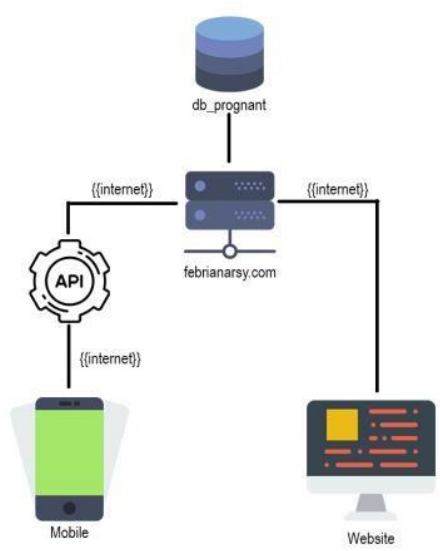


Gambar 5.4. Perancangan Jaringan

G. Implementasi Aplikasi

Berikut ini adalah beberapa tampilan aplikasi beserta langkah-langkah penggunaan nya :

1. Buka Aplikasi Prognant pada perangkat smartphone android anda

2. Kemudian akan masuk ke tampilan slider yang berisi sekilas tentang aplikasi Prognant.

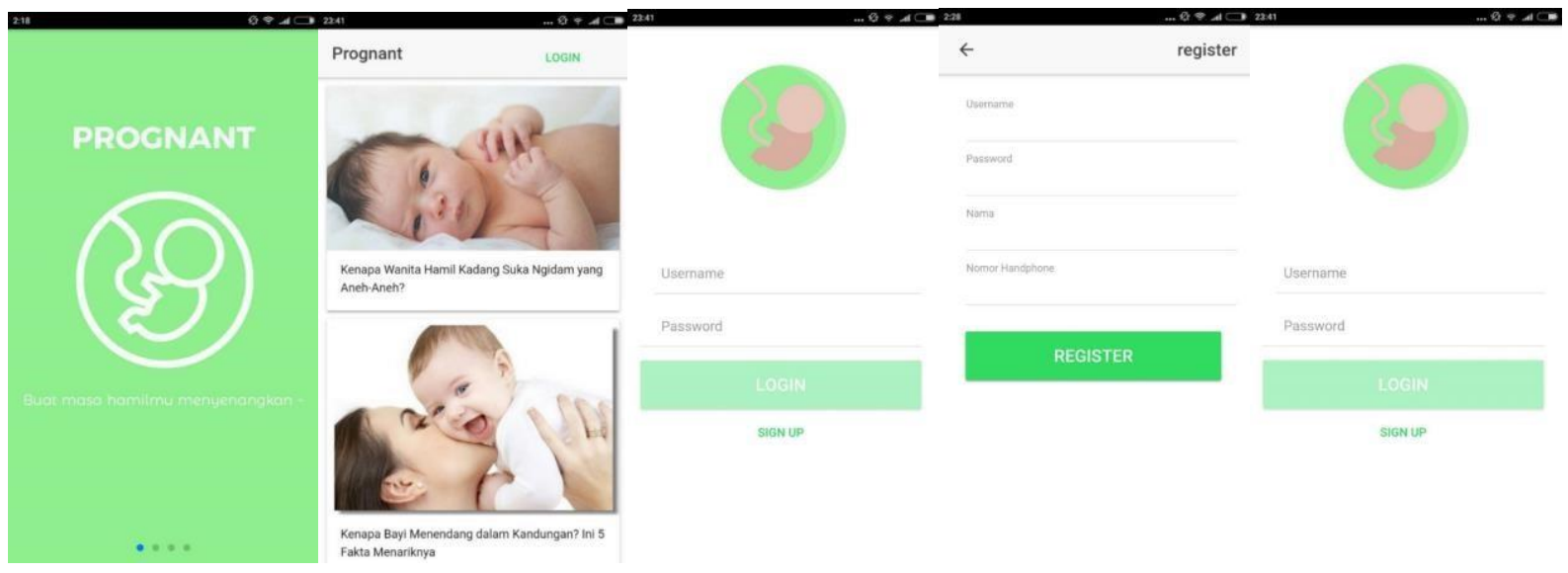

Gambar 4.5 Tampilan Awal aplikasi mobile

3. Namun sebelum bisa menjalankan semua fungsi anda harus ke klinik terlebih dahulu untuk melakukan pemeriksaan, hasil pemeriksaan akan diinputkan ke sistem oleh tenaga medis.

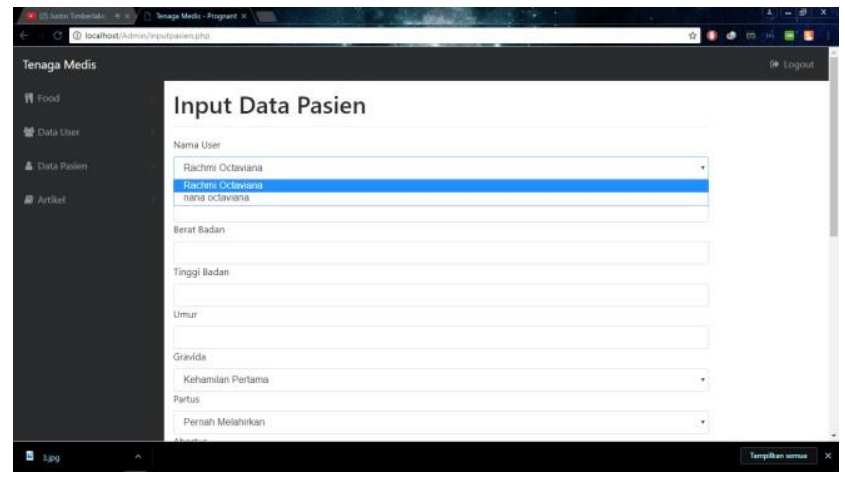

Gambar 4.6 Tampilan Input Data Pasien

4. Setelah melakukan pemeriksaan anda dapat melihant hasil pemeriksaan dengan memilih kandungan pada tab main, kemudian meilih tanggal pemeriksaaan.

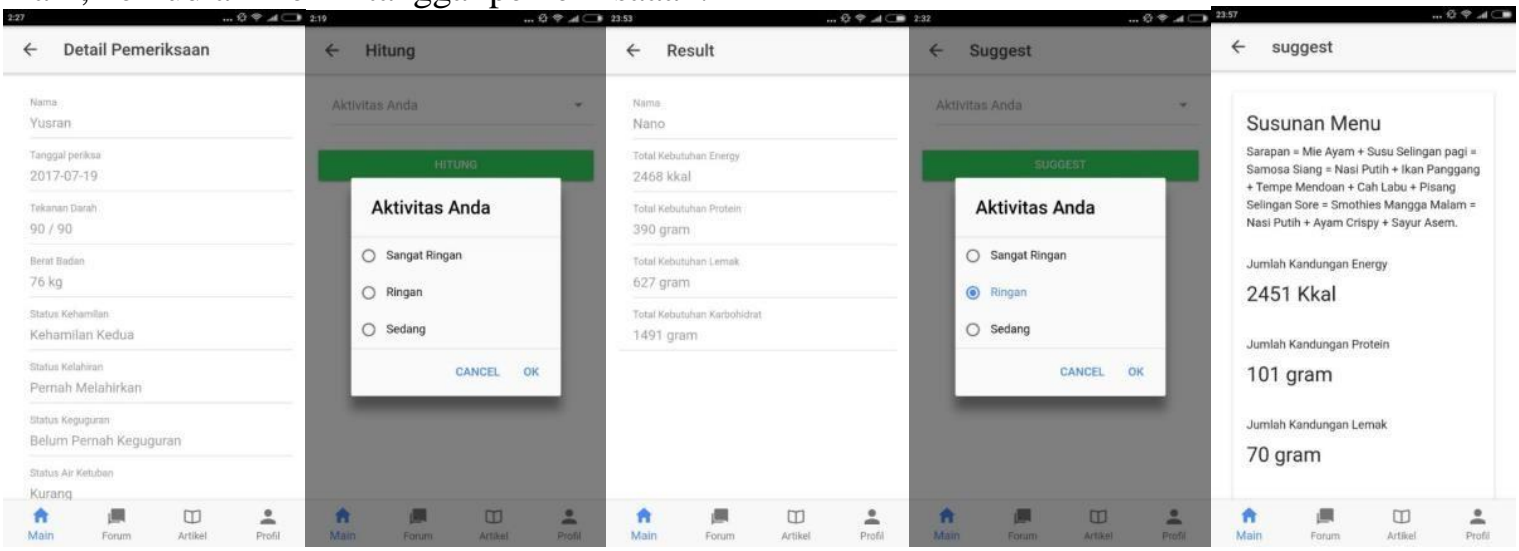

Gambar 4.7 Tampilan Detail Pemeriksaan 
5. Kemudian ahli gizi akan masuk ke website yang sudah disediakan sebagai ahli gizi, dan menjawab pertanyaan yang muncul.

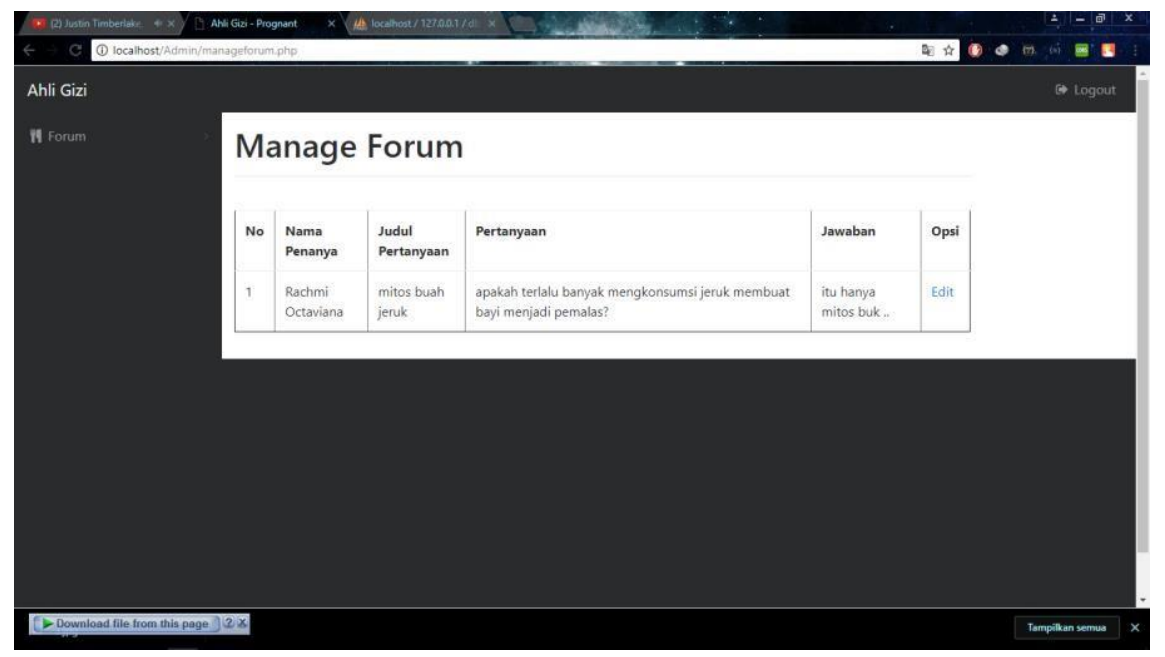

Gambar 4.8 Tampilan Manage Forum

\section{KESIMPULAN DAN SARAN}

\section{A. Kesimpulan}

Berdasarkan hasil yang didapat dari penelitian yang dilakukan dalam penyusunan skripsi ini serta mengacu pada tujuan penelitian, maka dapat disimpulkan :

1. Formula Harris Benedict dapat digunakan untuk menghitung energi yang dibutuhkan oleh ibu hamil yaitu dengan cara menghitung nilai Basal Metabolic Rate (BMR) dan aktivitas fisik.

2. Formula Harris Benedict untuk membantu menentukan kebutuhan energi ibu hamil, diimplementasikan dalam bentuk aplikasi berbasis android sehingga dapat dijadikan sebagai alat bantuk untuk ibu hamil (sebagai pengguna aplikasi).

3. Aplikasi penentu kebutuhan gizi ibu hamil ini dilengkapi dengan berbagai fasilitas seperti pendaftaran, pemeriksaan dan konsultasi yang diharapkan mampu menjadi sarana atau media pelayan antara ahli gizi (pihak klinik) dan ibu hamil.

\section{B. Saran}

Penulis mengajukan beberapa saran untuk pengguna dan pengembang aplikasi ini, adapun saran-sarannya sebagai berikut:

1. Tersedianya database menu makanan yang lebih variatif untuk ditawarkan terhadap ibu hamil dalam memenuhi kebutuhan gizinya.

2. Dapat menyediakan informasi resiko yang kemungkinan didapat oleh ibu hamil apabila kebutuhan gizinya tidak terpenuhi.

3. Diharapkan aplikasi ini tidak hanya membantu menentukan kebutuhan gizi terhadap ibu hamil melainkan juga untuk masyarakat secara umum.

4. Adanya penggunaan formula lain dalam menentukan kebutuhan gizi untuk ibu hamil.

\section{DAFTAR PUSTAKA}

[1] Almatsier S., dkk. 2011. Gizi Seimbang Dalam Daur Kehidupan. Jakarta: Gramedia Pustaka Utama.

[2] BPS, BKKBN dan Kementrian Kesehatan. 2013. Survei Demografi dan Kesehatan Indonesia 2012. Jakarta.

[3] Harris, J.A., Benedict. F.G. 1918. A Biometric Study of Basal Metabolism. Proceedings of the National Academy of Sciences, Volulem 4, Nomor 12, Desember 1918.

[4] http://www.uml-diagrams.org/uml-25-diagrams.html/ UML 2.5 Diagrams Overview / 1 Juni 2016.

[5] Pamungkas, G. A., Isnanto, R. R., \& Martono, K. T. 2016. Pembuatan Aplikasi Panduan Gizi Seimbang Berbasis Android Dengan Menggunakan Metode Backward Chaining. Jurnal Teknologi dan Sistem Komputer. Volume 4 Nomor 2 Halaman 369-379. 
[6] Roger S. Presman, Ph.D. 2012. Rekayasa Perangkat Lunak Pendekatan Praktisi (Buku Satu). Yogyakarta: Andi.

[7] Rosa, A.S. \& Shalahuddin, M. 2013. Rekayasa Perangkat Lunak: Terstruktur dan Berorientasi Objek. Bandung: Informatika.

[8] Safaat N.H. 2014. Android: Pemrograman Aplikasi Mobile Smartphone dan Tablet PC Berbasis Android. Bandung: Informatika.

[9] Simarmata, J. P., Siagian, A., \& Siregar, M. A. 2015. Gambaran Pola Makan Dan Status Gizi Ibu Hamil Di Wilayah Kerja Puskesmas Buhit Kecamatan Pangururan Kabupaten Samosir Tahun 2014. Jurnal Gizi, Kesehatan Reproduksi dan Epidemiologi. Volume 1 Nomor 4 Halaman 1-6.

[10] Sugiyono. 2010. Metode Penelitian Kuantitatif, Kualitatif, R\&D. Bandung: Alfabeta.

[11] Suryana, T. \& Koesheryatin. 2014. Aplikasi Internet Menggunakan HTML, CSS, dan JavaScript. Jakarta: Elex Media Komputindo.

[12] Vita K.M. 2014. Faktor-Faktor Yang Berhubungan Dengan Kekurangan Energi Kronis (KEK) Pada Ibu Hamil Di Kecamatan Kamoning Dan Tambelangan, Kabupaten Sampang, Jawa Timur. Buletin Penelitian Sistem Kesehatan. Volume 17 Nomor 2 Halaman 193-202. 